\title{
LATE-QUATERNARY VEGETATIONAL AND CLIMATIC HISTORY OF THE YELLOWSTONE/GRAND TETON REGION
}

Cathy whitlock Barnosky Carnegie Museum of Natural History

4400 Forbes Avenue

Pittsburgh

\section{objectives}

The research underway focuses on the vegetational history of the Greater Yellowstone Ecosystem and the response of plant communities to environmental changes of varying intensity and duration. Four studies are in progress and at different stages of completion. In two investigations, processes operating on time scales of centuries and millennia are being studied to reconstruct the long-term environmental changes of the last 14,000 years. In a third study, a time scale of decades or less helps to clarify the nature of Yellowstone's northern range prior to and since the establishment of the Park. Finally, focusing on a time scale of years or less, we are investigating the sedimentary inputs in the aftermath of the 1988 fires to determine the processes by which lake sediments record fire events. An examination of the paleoecologic record on these different time scales provides information on the relative sensitivity of plant communities and lake systems to long-term and short-term disturbances, and adds to our knowledge of the postglacial history of the northern Rocky Mountains.

\section{Methods}

A detailed description of the research methodology is included in the proposal and will not be repeated here. In order to accomplish the objectives, we have undertaken the following tasks:

(1) A reconstruction of the postglacial vegetation of the Yellowstone/Grand Teton region from pollen and macrofossil records. Fossil pollen in lake-sediment cores have been analyzed to clarify the nature and composition of ice-age refugia, the rate and direction of plant migrations in the initial stages of reforestation, and the long-term stability of postglacial communities. In a transect extending from northern Jackson Hole to the 
southern boundary of Yellowstone Park, cores have been obtained from six lakes. At each site, stratigraphic records of pollen percentages, pollen accumulation rates, and plant macrofossils have been analyzed. Radiocarbon dates and identification of tephra layers of known age have provided the chronology for the fossil record. The interpretation of the fossil pollen data rests on the relationship between modern pollen rain and present-day vegetation (Barnosky 1986). This year a record from Cygnet Lake, located on the Central Plateau, was studied to provide information on the history of the vast lodgepole pine forest that covers much of Yellowstone (Fig. 1).

(2) An investigation of the relationship of climate to sedimentation rates in lakes and ponds in Yellowstone, undertaken with colleagues from the University of Minnesota (Wright et al. 1989; Barnosky et al. in press; Engstrom et al. in review). This facet of the research examines the relative importance of climate, fire, hillslope erosion induced by grazing, and nutrient enrichment in the last 150 years, as recorded in selected lakes in the northern range of Yellowstone. Pollen, diatoms, charcoal, sediment chemistry, and sediment accumulation rates were analyzed in short cores from small lakes.

(3) A study of the paleolimnology of Alder Lake to determine its history relative to that of nearby Yellowstone Lake (Fig. 1). A sedimentologic, diatom, and pigment analysis of a $10.7 \mathrm{~m}$ core from Alder Lake helps date the prominent $20 \mathrm{~m}$ terrace around Yellowstone Lake and subsequent lakelevel fluctuations that isolated and reconnected Yellowstone and Alder lakes (Sherrod 1989).

(4) A study of fire history for Yellowstone that extends beyond the range covered by dendrological studies. The primary data base is sedimentary charcoal in lake cores, and its relative abundance through time. The fires of 1988 in Yellowstone provide a set of conditions that help determine the relationship between vegetation, climatic change, and fire frequency on short-term and long-term time scales. Field studies since 1988 monitor the biological and sedimentary inputs into lakes following the recent fires (sites on Fig. 1). The calibration of these inputs--sedimentary charcoal, pollen, and magnetic minerals--with size and type of burn will be the basis for reconstructing past fire conditions from the stratigraphic record. 


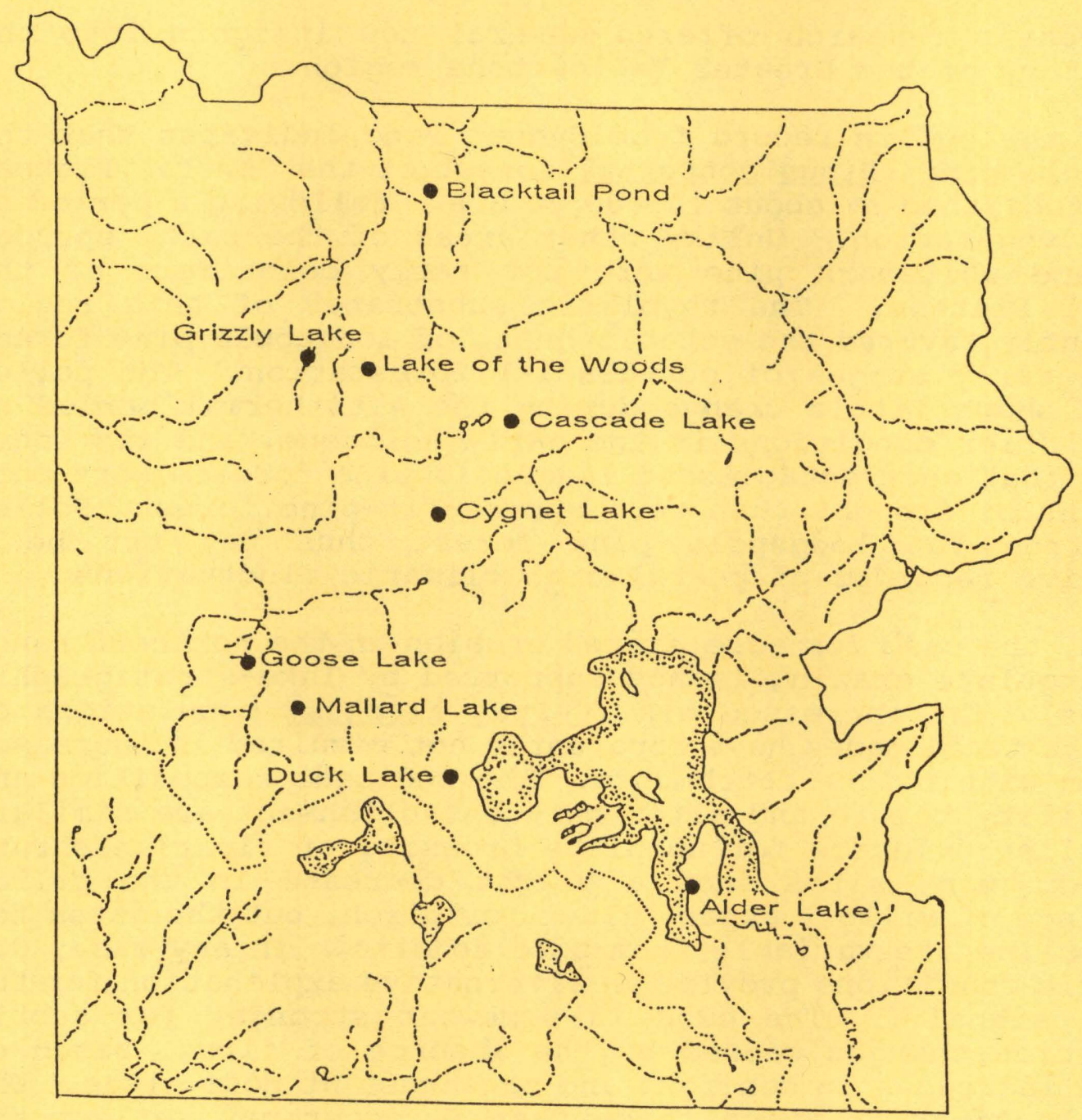

Figure 1. Location of sites discussed in this report. 


\section{Results}

This year's research offered several new insights into the prehistory of the Greater Yellowstone region.

First, the pollen record from cygnet Pond indicates that the lodgepole pine (Pinus contorta) forest of the Central Plateau was established at about $10,000 \mathrm{yr}$ B.P., following a period of tundra vegetation. Unlike other areas of the park, spruce, fir, and whitebark pine were not early colonizers of the Central Plateau. The rhyolitic substrates of this region apparently favored the establishment of lodgepole pine forest in the early stages of postglacial forestation. The pollen record shows little change during the Altithermal period of warmer drier conditions in the early Holocene, and its seems likely that once established lodgepole pine forests were more tolerant of drought than were spruce-fir-pine forest. Pollen data from the lodgepole pine forest thus may not be a sensitive recorder of postglacial climatic fluctuations.

Second, the case for accelerated erosion in the northern range from ungulate grazing is not supported by lake-stratigraphic studies. The increased elk (Cervus elaphus) populations of the last two decades have apparently not resulted in increased erosion within lake catchments. The sediment composition and variability before and after park establishment are similar. The pollen evidence for ungulate browsing of riparian shrubs is weak: many sites show a slight decrease in the pollen abundance of willow, aspen, alder, or birch, but the dates for the decline are variable from site to site. In any case, dry climatic conditions provide an alternative explanation for the pollen signal. The case is somewhat stronger for subtle vegetation changes caused by the absence of fires, based on pollen increases in conifers and sagebrush at most sites. The variable times at which these changes occur may reflect the different response times of the various conifers to a change in fire regime.

Third, the postglacial diatom and pigment record from Alder Lake provides critical information on the history of Yellowstone Lake. Prior to 10,700 yr B.P. Alder Lake was part of a large oligotrophic Yellowstone system that had a water depth $20 \mathrm{~m}$ or more above present lake surface. After 10,700 yr B.P., the water level lowered and Alder Lake became isolated from Yellowstone Lake, first as a shallow embayment separated by a spit, and later as a lake both larger and deeper than the present system. The sediments, diatoms, and pigments indicate that Alder Lake was meromictic in the early Holocene, with anoxic conditions in the deepest part 
preserving distinct annual laminations. During the Altithermal, the lake became more eutrophic and nutrient enriched. After 4300 yr B.P., the diatom data indicate a more mesotrophic status for Alder Lake. The late-Holocene record suggests at least one period of higher water level, which reestablished the connection between Yellowstone and Alder lakes. This event is dated in the core ca. $3000 \mathrm{yr} \mathrm{B.P.,} \mathrm{and}$ probably corresponds to a major southward tilting of the basin.

Fourth, charcoal contained in sediment cores from the deepest part of lakes have been used to reconstruct past fires in several regions. Yet the interpretation of charcoal size and abundance in terms of specific burn conditions has never been quantified. Preliminary studies of charcoal in the surface sediments of Duck Lake indicate that charcoal ranging in size from 0.125 to $0.250 \mathrm{~mm}$ is most useful for reconstructing local fire events. This size fraction is relatively abundant at all water depths, unlike larger size fractions, and yet it is large enough not to be transported far from source. Much of the charcoal introduced directly from atmospheric fall-out last summer has not yet reached the deepest part of the basin. This means that there is an intrinsic lag in charcoal records with respect to the actual fire event. Sediment focusing over the next few years should shift the distribution of charcoal from shallow to deep water. In addition, analysis of data collected in summer 1989 will determine if erosion and slope processes following snowmelt introduce significant charcoal to the system. Analysis of short cores from Mallard Lake shows periods when charcoal concentration exceeds background level. Lead-210 dating of these periods will determine how closely these charcoal peaks match known fire events.

\section{Conclusions}

A knowledge of prehistory is essential for understanding the spatial complexity of the modern biota and the sensitivity of the Yellowstone/Grand Teton region to environmental disturbance. On a time scale of thousands of years, the research underway shows major changes in vegetation since the retreat of glacial ice. These changes reflect the early colonization of the region during initial climatic warming and the development of modern plant associations in response to changes in climate, soil, and disturbance regime. Lakes within the Park are also sensitive indicators of environmental change and provide a history of limnologic succession, climatic change, and lake-level fluctuations related to regional tectonism. 
On a shorter time scale, the prehistoric record shows environmental changes that are more localized and regionally metasynchronous. Within the last 150 years, human and natural disturbances have not caused major perturbations of vegetation or limnologic systems in Yellowstone's northern range, although specific sites have apparently been affected by one or more of these variables at different times. Unlike the long-term changes that affect the entire Yellowstone region, however, each catchment has responded individualistically to the short-term changes in ungulate usage, hydrology, fire regime, and microclimate.

With the fires of 1988 as a modern analogue, we have an opportunity to better understand the long-term frequency of fires in Yellowstone and how it is affected by climate and determines plant-community composition through time. A calibration of modern fire inputs into lakes provides an exciting paleoecologic tool for reconstructing past fires from sedimentary charcoal, pollen, and magnetic minerals in lake cores.

\section{Literature Cited}

Barnosky, C.W. 1986. Late-glacial and postglacial vegetation and climate of Jackson Hole and the Pinyon Peak Highlands. Annual Report to the UW-NPS Research Center, $25 \mathrm{pp}$.

Engstrom, D.R., C. Barnosky Whitlock, S.C. Fritz, and H.E. Wright, Jr. In review. Recent environmental changes inferred from the sediments of small lakes in Yellowstone's Northern Range. Ecological Monographs.

Sherrod, B.S. 1989. Paleolimnology of Alder Lake and its implications for Holocene tectonics in Yellowstone National Park. M.S. Thesis, University of Pittsburgh, 47 pp.

Wright, H.E., Jr., C.W. Barnosky, D.R. Engstrom, and S.C. Fritz, S.C. 1989. Limnological and environmental changes inferred from the sediments of small lakes in the northern range of Yellowstone National Park. Final Report to the UW-NPS Research Center, $25 \mathrm{pp}$. 
Whitlock Barnosky, C., S.C. Fritz, and D.R. Engstrom. In press. A prehistoric perspective on Yellowstone's Northern Range. in The Greater Yellowstone Ecosystem: Balancing Man and Nature on America's Wildlands. R.B. Keiter and M.S. Boyce, eds). Yale University Press, New Haven, CT. 